\title{
AIRBORNE AND GROUND GEOPHYSICS APPLIED TO GROUNDWATER PROSPECTION IN HARD ROCKS IN IRAUÇUBA, CEARÁ STATE, BRAZIL
}

\author{
Tercyo Rinaldo Gonçalves Pinéo ${ }^{1}$, Raimundo Mariano Gomes Castelo Branco², \\ Luciano Soares da Cunha ${ }^{3}$ and Mauro Lisboa Souza ${ }^{1}$
}

\begin{abstract}
This work involved geophysical prospecting techniques, remote sensing and litho-structural recognition, applied to groundwater research in a region formed by hard rocks located in Irauçuba, Ceará State, Brazil. Geophysical magnetic and electromagnetic airborne data compiled from PROASNE project (Projeto Água Subterrânea do Nordeste do Brasi/), Landsat ETM7 satellite images and electromagnetic land data, acquired in this research, were studied and allowed mapping lineaments related to geological structures, properly characterized by structural recognition on the field. The integrated analysis of geophysical and geological data, including hydrogeological information from deep wells, allowed understanding the pattern of fractures in the area, correlating the structures with the geological event responsible for their genesis and determining their hydrogeological potential. The results culminated in a structural-hydrogeological local model to be applied in areas with similar geological features. According to this model, geological brittle structures with approximate N-S direction are little penetrative and contribute to the recharge structures of WNW-ESE direction, which are the most promising for groundwater exploitation through deep wells.
\end{abstract}

Keywords: groundwater in hard rocks, geophysics prospection, remote sensing.

RESUMO. Este trabalho envolveu técnicas geofísicas de prospecção, sensoriamento remoto e reconhecimento lito-estrutural, aplicados à pesquisa de água subterrânea em uma região formada por rochas cristalinas, localizada no município de Irauçuba, Estado do Ceará, Brasil. Dados geofísicos magnéticos e eletromagnéticos aerotransportados compilados do projeto PROASNE (Projeto Água Subterrânea do Nordeste do Brasil), imagens do satélite LandSat ETM7 e dados eletromagnéticos terrestres, adquiridos nesta pesquisa, foram trabalhados de forma integrada e permitiram cartografar lineamentos referentes a estruturas geológicas diversas, devidamente caracterizados através de reconhecimento estrutural em atividade de campo. A análise integrada dos dados geofísicos e geológicos, incluindo informações hidrogeológicas de poços profundos, possibilitou compreender o padrão de fraturas da área, correlacionar as estruturas com o evento geológico responsável por sua gênese e determinar o potencial hidrogeológico destas estruturas. Os resultados obtidos culminaram em um modelo estrutural-hidrogeológico local, de aplicação em áreas com características geológicas similares. De acordo com o referido modelo, estruturas geológicas rúpteis de direção aproximada N-S são pouco penetrativas e tem como função principal contribuir com a recarga das estruturas de direção WNW-ESE, que são mais promissoras a explotação de água subterrânea por meio de poço tubular profundo.

Palavras-chave: aquifero fissural, geofísica de prospecção, sensoriamento remoto.

\footnotetext{
${ }^{1}$ Serviço Geológico do Brasil (CPRM), Avenida Antônio Sales, 1418, Joaquim Távora, 60135-101 Fortaleza, CE, Brazil. Phone: +55(85) 3878-0200; Fax: +55(85) 3878-0240 - E-mails: tercyo.pineo@cprm.gov.br; mauro.lisboa@cprm.gov.br

2Laboratório de Geofísica de Prospecção e Sensoriamento Remoto (LGPSR), Universidade Federal do Ceará, Avenida do Contorno, s/n, 60455-760 Fortaleza, CE, Brazil. Phone: +55(85) 3366-9870 - E-mail: mariano@ufc.br

3 Instituto de Geociências, Universidade de Brasília, UnB, Asa Norte, 70910-900 Brasília, DF, Brazil. Phone: +55(61) 3107-6994; Fax: +55(61) $3272-4286$ - E-mail: lucianosc@unb.br
} 


\section{INTRODUCTION}

The sertão region of Ceará state, like much of the Northeast, has semi-arid climate characterized predominantly by drought that gives a typically ephemeral nature to the rivers in the region. The low rainfall is also associated with shallow and immature soils which are superimposed on crystalline rocks with no primary porosity, bringing down the groundwater potential. In other words, the study regional is precarious in terms of surface and groundwater resources. To make things worse, the region has high evaporation rates due to high temperatures almost year-around. Hence, the population lives in hostile conditions and every viable multidisciplinary research effort aiming at improving water supply is essential.

Despite the unfavorable lithological framework, groundwater research and exploration in Ceará State are seen as an alternative water supply for the population. According to SIAGAS (Sistema de Informação de Águas Subterrâneas - Groundwater Information System) database of CPRM (Serviço Geológico do Brasil), accessed in July 2012, there are approximately 20,800 deep wells registered in Ceará State, of which approximately $75 \%$ are located in crystalline rock areas.

On land formed by crystalline rocks, groundwater is stored in open brittle geological discontinuities such as faults, fractures and joints, constituting the fractured aquifers. The presence of water in these structures creates a good resistivity contrast compared to adjacent non-fractured rocks (Yadav \& Singh, 2007), so the electromagnetic geophysical methods are widely applied to map brittle structures capable of storing water in the subsurface (Porsani et al., 2005; Feitosa et al., 2008). This method also provides information on water quality and aquifer conditions since the investigated parameter is electrical conductivity (Paterson \& Bosschart, 1987; Siemon et al, 2009; Souza Filho et al., 2010; Siemon et al., 2011).

The presence of magnetite crystals between the planes of a geological structure allows applying magnetometry for its recognition (Ranganai \& Ebinger, 2008), thus characterizing the region structural framework. There are few studies in the literature on the application of magnetometry in groundwater surveys, especially in Brazil (Oliveira et al., 2003). However, the magnetic data processing techniques applied to groundwater surveys in a fractured medium are similar to the techniques applied to geological mapping and mineral exploration (Reeves \& Zeil, 1990; Ranganai \& Ebinger, 2008).

The spatial arrangement between the brittle and ductile geological structures can also be understood through analysis of satellite images and aerial photographs, applied extensively in research of groundwater in fractured media (Sander, 2007).
Therefore, this work aims to suggest fracture zones favorable to groundwater flow and storage in the western region of Ceará (Fig. 1) by applying the geophysical methods cited, integrated with remote sensing images, litho-structural data obtained in the field and deep wells hydrogeological data compiled from SIAGAS/CPRM. The results led to the proposition of a structuralhydrogeological model for the study area, which can guide future work on water prospecting in crystalline/hard rock terrain with similar fracturing pattern.

\section{STUDY AREA}

The 154-km² study area is located in the Northwest region of the Ceara Central Domain and belongs to the Northern Borborema Province (Almeida et al., 1981; Brito Neves et al., 1999; Delgado et al., 2003). The local geological setting is characterized by lithotypes of the Tamboril-Santa Quiteria Complex and the Independência and Canindé Units lithotypes of the Ceará Complex (Cavalcante et al., 2003) (Fig. 1).

The Tamboril-Santa Quitéria Complex outcrops at the area northern end and corresponds to a granite-migmatitic association containing gray and pink granitoids of varying granulation up to porphyritic, gneissified or not, as well as migmatitic paragneiss and orthogneiss, calcium-silicate rocks and amphibolites. The Tamboril-Santa Quitéria Complex was defined as a continental magmatic arc of the Neoproterozoic, developed between 660 and $590 \mathrm{Ma}$ (Fetter et al., 2003).

The Independência Unit is located in the area western end, comprising predominantly of micaschists, followed by paragneisses and quartzites. The Canindé Unit consists of paragneisses associated with bentonite stratoids of neoproterozoic granites, gneissified or not, and lenses of quartzite, marble, calciumsilicate rocks and amphibolite. The Ceará complex is also Neoproterozoic (Fetter, 1999; Castro, 2004; Arthaud, 2007; Torres et al., 2007).

According to the CPRM/SIAGAS database (accessed in July 2012), the area has 23 deep wells with an average depth of 60 meters, of which only seven are productive. Of these, three have outflow of $6 \mathrm{~m}^{3} / \mathrm{h}$ and the rest have an average outflow of $1.5 \mathrm{~m}^{3} / \mathrm{h}$ (Fig. 1). According to Souza Filho (1999), the most frequent maximum depths of water inlet are between 20 and 40 meters, in Irauçuba region.

\section{MATERIALS AND METHODS}

This study started with the integrated processing and interpretation, in GIS, of airborne geophysical data (magnetic and electromagnetic) and LandSat ETM7 satellite images. From the obtained results the ground electromagnetic profiles were pro- 


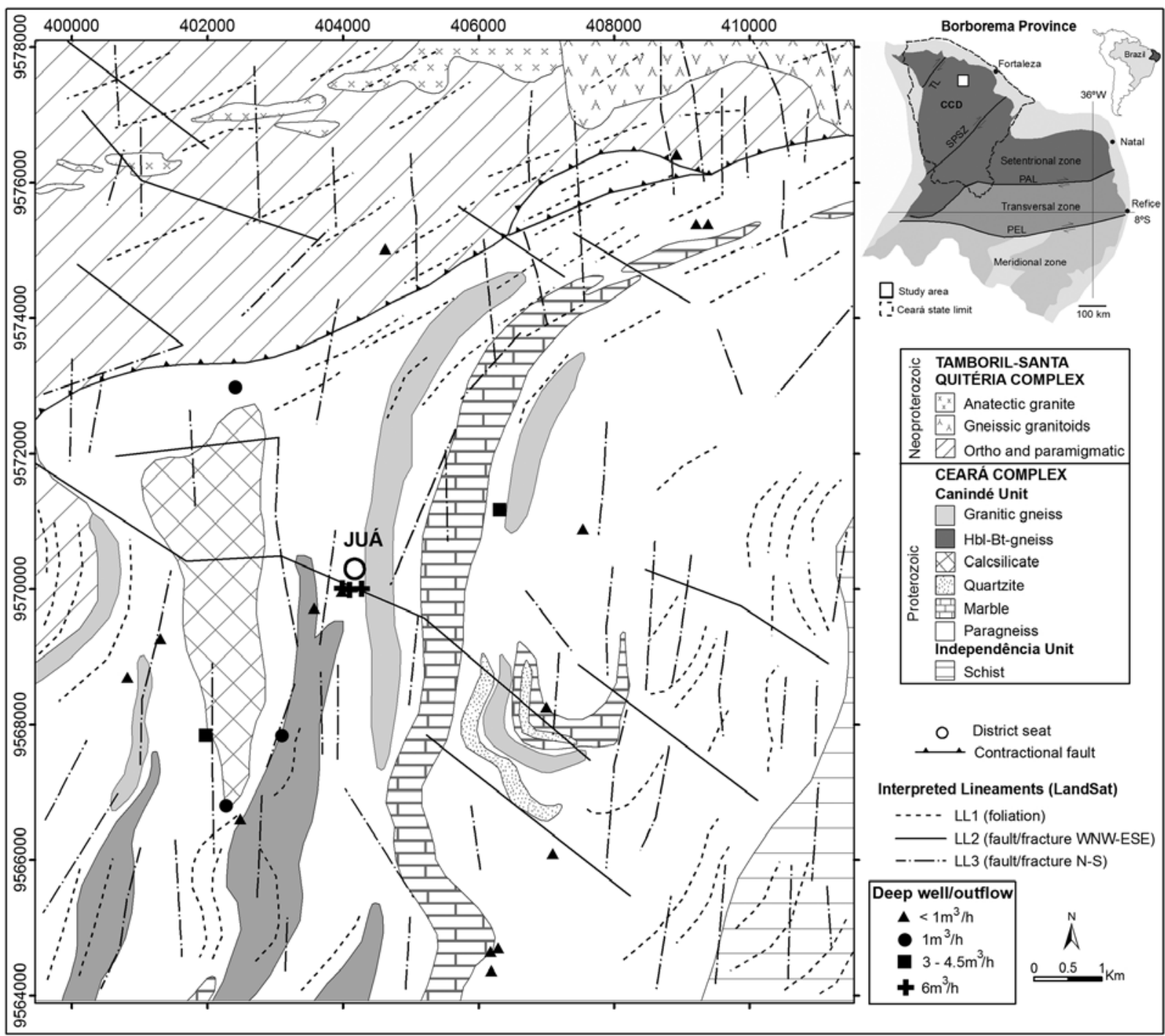

Figure 1 - Simplified geological map of the study area, with location of deep wells and the lineaments analyzed from Landsat imaging (LL1, LL2 and LL3). Modified from Cavalcante et al. (2003), Souza Filho (1998) and Delgado et al. (2003). TL - Transbrasiliano Lineament, PLA - Patos Lineament, PEL - Pernambuco Lineament, SPSZ - Senador Pompeu shear zone, CCD - Ceará Central Domain. UTM projection, Zone 24 South, Datum WGS-84.

grammed. Data interpretation was focused on determining and analyzing the geophysical anomalies related to geological structures to define the structural pattern of the area and, therefore, its hydrogeological potential.

The airborne geophysical data from the PROASNE (Projeto Água Subterrânea do Nordeste do Brasil) resulted from the partnership between the Serviço Geológico do Brasil (CPRM) and the Geological Survey of Canada (GSC) and were acquired by LASA Engineering and Prospecting S.A. This project was carried out between 2000 and 2001 in an area of $154 \mathrm{~km}^{2}$ totaling $1,873 \mathrm{~km}$ of profile. The flight lines had direction of $\mathrm{E}-\mathrm{W}$ and line spacing of $100 \mathrm{~m}$ and the control lines, had direction N-S and $500 \mathrm{~m}$ spac- ing. Sensor height with respect to terrain was $30 \mathrm{~m}$ and the sampling interval, $0.1 \mathrm{~s}$. The aeromagnetic data was acquired using the Geometrics G-822A equipment and the aero-electromagnetic data through the DSP-99-Aerodat system, operated with two pairs of coaxial coils at 900 and $4500 \mathrm{~Hz}$ frequencies and three pairs of coplanar coils at $900,4,500$ and $33,000 \mathrm{~Hz}$ frequencies (LASA, $2001-<$ http://proasne.net>).

The geophysical data processing was done with Oasis montaj $^{\text {TM }} 7.2 .1$ software from Geosoft. After a quality analysis, the data was then interpolated using the minimum curvature method (25 m $\times 25 \mathrm{~m}$ grid), followed by application of Upward Continuation filter in the Fourier domain, for noise removal, 
using a $150 \mathrm{~m}$ upwarded flying height as parameter. The images related to the anomalous magnetic field and the first vertical derivative were generated and interpreted from the aeromagnetic data. Apparent conductivity images for coaxial dipole mode were created and analyzed from the aero-electromagnetic data, at 900 and $4500 \mathrm{~Hz}$ frequencies, since they characterize better vertical geologic structures, such as faults and fractures (Siemon et al., 2011).

Satellite imaging is a powerful tool in structural analysis of large areas and thus extensively applied for water prospecting in fractured areas (Coriolanus, 2002; Leite, 2008; Ranganai \& Ebinger, 2008). The remote sensing images used are from the scene 217_063, obtained in October 1999 by the ETM7 sensor of theLandsat satellite. These images were processed using the ERDAS ER Mapper 7.0 software to create colorful compositions between spectral bands and primary colors (red, green and blue), contrast adjustments, and a high-pass filter to enhance the elements represented by high frequencies, especially geological structures.

The ground electromagnetic survey used the equipment EM34-3XL, developed by Geonics Limited (McNeill, 1980), along three regional profiles with 40-m reading stations spacing, totaling 9560 meters of profile. The E-W profiles were created based primarily on the N-S conductive anomalies of the aero-electromagnetic map and on the lineaments defined by remote sensing imaging. The profiles were surveyed with all possible arrangements (DH-10, DV-10, DH-20, DV-20, DH-40 and DV-40) and the acquired data was organized in an Excel spreadsheet, to prepare the profiles for conductive anomalies analysis.

\section{RESULTS}

\section{Aero magnetometry}

The aeromagnetic data analysis focused on determining and characterizing the magnetic lineaments related to geological structures. Therefore, three groups of magnetic lineaments were formed based on the image of the first vertical derivative taken from the anomalous magnetic field (Fig. 2).

The first group corresponds to meandering magnetic lineaments with approximate N-S direction, turning to NE-SW, referred to as ML1. They are located in the Central-Eastern portion of the area and are in alignment with the tectonic metamorphic foliations trend measured in the field and observed in Landsat ETM7 satellite images. Some of these lineaments correspond to the contact between different lithotypes, according to the geological map (Fig. 1). Hence, they are properly interpreted as duc- tile discontinuities (shear zones and tectonic metamorphic foliations) originated in compressional tectonic regime and, thus, of no importance from the view point of groundwater prospecting, since these geological structures have no significant secondary porosity.

Associated with the same compressional dynamics followed by shearing, there are ENE-WSW rectilinear magnetic lineaments (ML2) interpreted as a shear zone that marks the contact between the igneous rock types of the Tamboril-Santa Quiteria complex in the North and the supracrustal rocks of the Ceará Complex in the South, of no importance for groundwater prospecting. These discontinuities also occur within the Tamboril-Santa Quiteria complex, as shown by linear magnetic anomalies.

The third group of WNW-ESE magnetic lineaments (ML3) intersects the other two groups, indicative of a newer structure. Some ML3 lineaments are related to rectilinear lineaments identified on Landsat ETM7 images and to fractures observed in the field. Hence, they are interpreted as corresponding to more penetrative brittle discontinuities (faults/fractures) favorable to groundwater storage. The most productive deep wells are associated with one of these lineaments, located in the central area and close to the Jua district.

\section{Aero-electromagnetic data}

The analysis of aero-electromagnetic data also focused on differentiating anomalous lineaments related to geological structures; however, it was also possible to individualize/distinguish geoelectric domains related with the lithological units relevant to the study area (Fig. 3). In the southeastern end area, there is a conductive domain (A), with amplitudes over $40 \mathrm{mS} / \mathrm{m}$, correlated to a region composed of various shales from the Independência unit, where the rock structural frame, characterized by penetrative foliation allows the influx of meteoric fluids resulting in a relatively conductive ground. This region may also represent an important recharge zone of proximal fractured aquifers.

The second geophysical domain (B) is predominant, has amplitudes lower than $7 \mathrm{mS} / \mathrm{m}$, corresponds to the area's central region and consists of gneiss, marble, quartzite and orthogneiss, relatively resistive compared to the adjacent schist domain. In the Northern end of the area we find domain (C) that consists predominantly of resistive rocks, with amplitudes of the order of $1 \mathrm{mS} / \mathrm{m}$, generally correlated to orthogneiss and orthomigmatites of the Tamboril-Santa Quitéria Complex.

Relatively conductive NNW-SSE axes (EML1) are common throughout the area, up to 6-km long and with about $12-\mathrm{mS} / \mathrm{m}$ average apparent conductivity. There are also conductive WNWESE axes (EML2) approximately 6-Km long and with 30-mS/m 


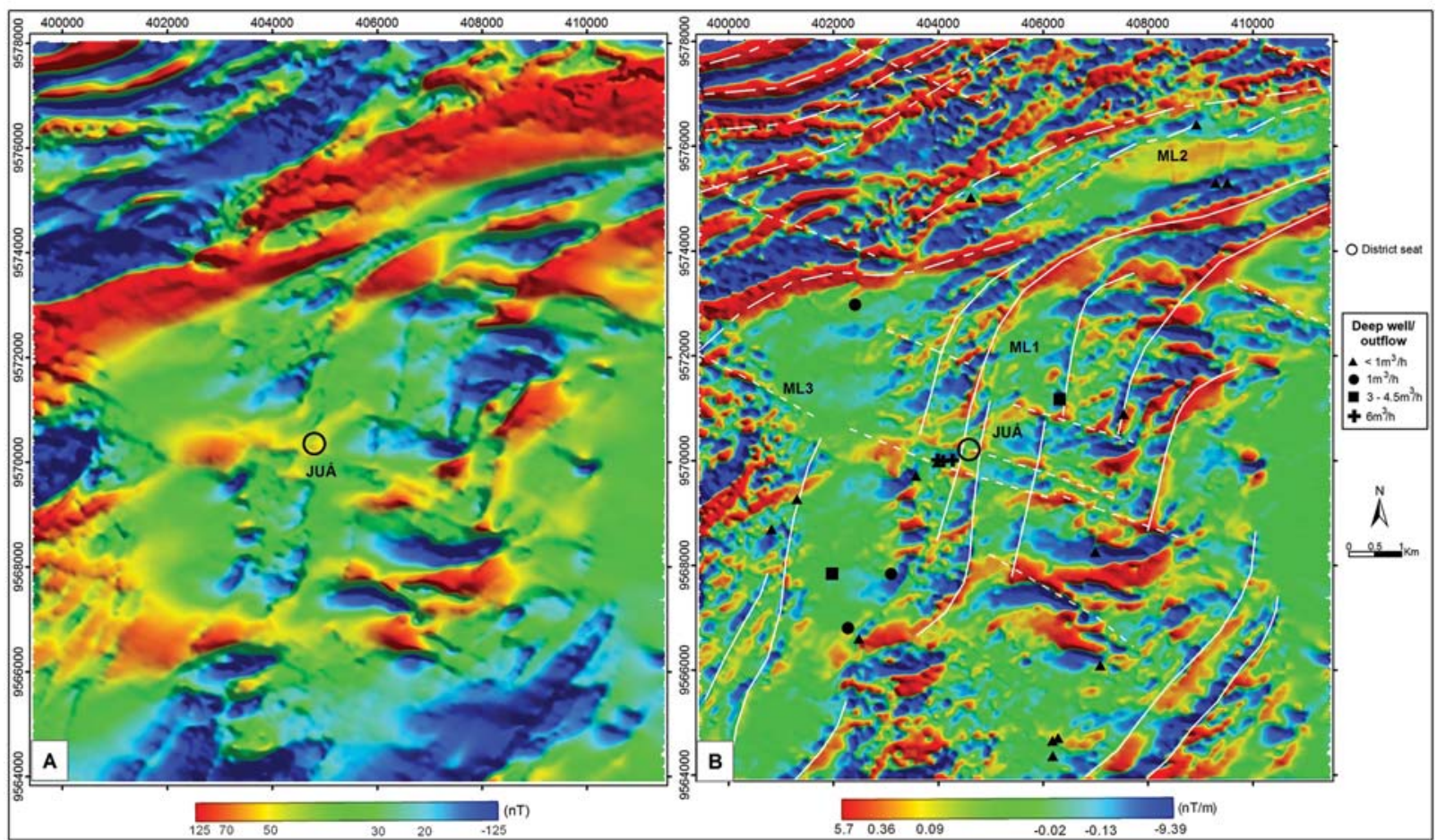

Figure 2 - Images of the anomalous magnetic field (A) and first vertical derivative with the interpreted magnetic lineaments and the deep wells (B) superimposed. Shaded images: Slope $=45^{\circ}$, declination $=45^{\circ}$ Az. ML - Magnetic Lineament (ML1: solid white line, ML2: white line big/small dash, ML3: dashed white line).

apparent conductivity, related to the magnetic lineaments ML3, thus corresponding to more penetrative brittle discontinuities (faults/fractures). Wells with approximately $6 \mathrm{~m}^{3} / \mathrm{h}$ outflow are associated with one EML2 electromagnetic lineament, near the Juá district, while wells of relatively small outflow, equal to or less than $1 \mathrm{~m}^{3} / \mathrm{h}$ are associated with EML1 lineaments (Fig. 3).

\section{LandSat ETM7 Images and field geological data}

The Landsat satellite images allowed identifying three sets of lineaments (Fig. 1). The first (LL1) is winding, with direction varying from NE-SW to $\mathrm{N}-\mathrm{S}$. These lineaments are related to tectonic-metamorphic foliations registered in the rocks during the compression stage associated with the Brasiliano/Pan-African orogeny. The second set (LL2) is represented by straight topographic valleys, some coincident with river bed, in the WNW-ESE direction and related to brittle geological discontinuities. Some of the most productive deep wells in the area are associated with one of these structures, near the Juá district. Lineaments along the NNW-SSE/NNE-SSW direction (LL3) are also characterized by topographic valleys, although with subtle evidence, and are associated with brittle discontinuities and intersect the LL1 lineaments. The least productive wells are associated with LL3.
Landsat images are not displayed in this work, since they do not have adequate spatial resolution to distinguish the different elements extracted and identified in them, which are easily visualized with computing resources using appropriate software.

The lineaments interpreted from Landsat and airborne geophysical images were properly checked in the field. Thus, 116 fracture attitude measurements, which are presented in a rosette diagram (Fig. 4A), were obtained in 57 rock outcroppings. The field data identified two preferred fracturing directions, WNWESE and NNW-SSE, related to LL2 and LL3 Landsat lineaments, respectively (Fig. 1). Overall, these structures have vertical to subvertical dips.

Among the tectonic events responsible for the development of the brittle structural framework of the crystalline massifs in Borborema Province presented by Jardim de Sá et al. (2008), two apply to the fracture pattern relevant to the survey area, as summarized in Table 1. Thus, the WNW-ESE lineaments (ML3, EML2 and LL2) identified in the airborne geophysical data, Landsat images and field work are associated with the exhumation of the land after the Brasiliano Orogeny, in the CambroOrdovician. This extensional tectonic event favored the development of penetrative fractures, which have an orthogonal geometric relationship with respect to transcurrent shear zones of NESW direction, characteristic of the Borborema Province (Fig. 4B). 


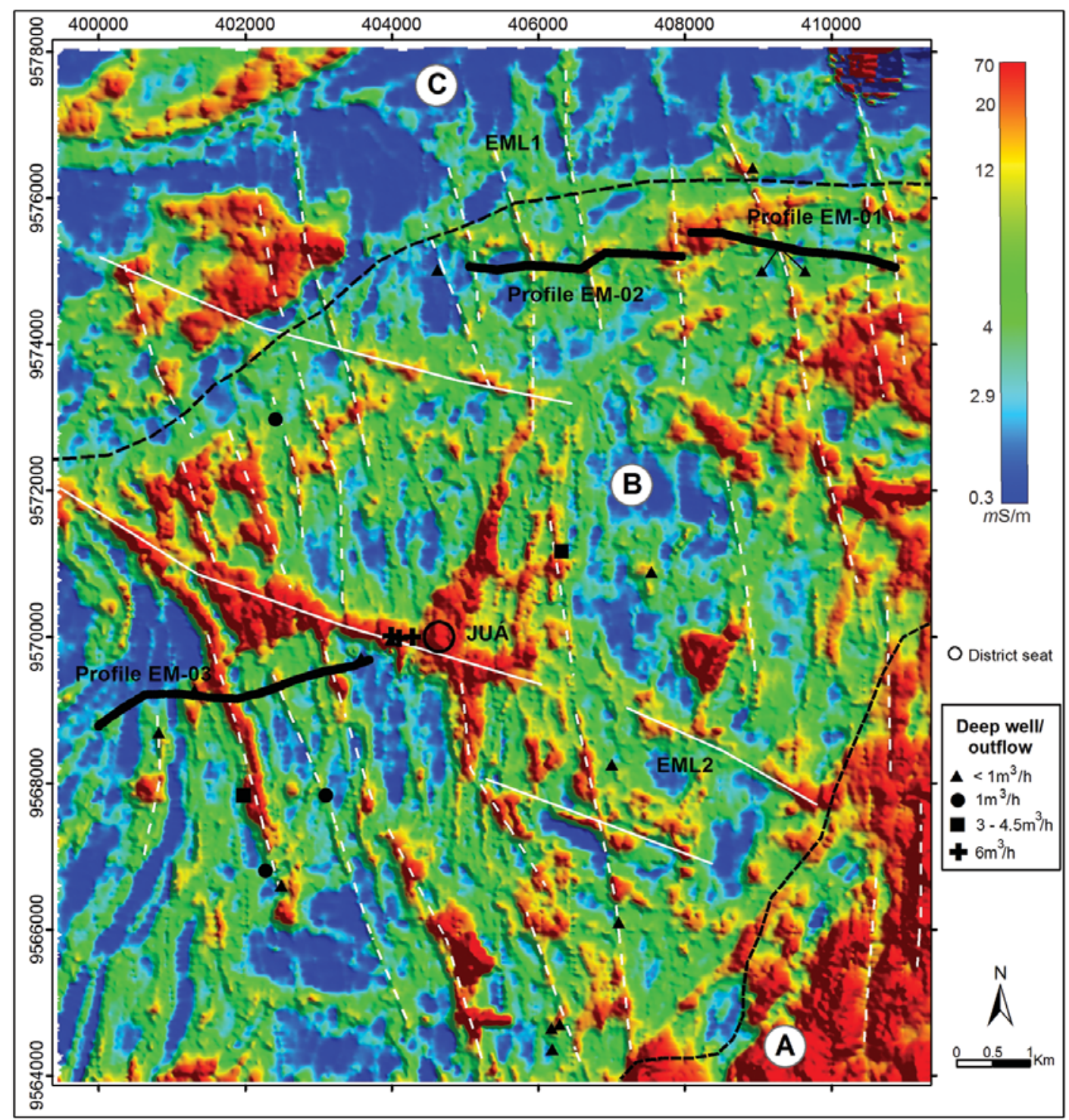

Figure 3 - Image of aero-eletromagnetic data with the interpreted conductive lineaments (in white), the terrestrial electromagnetic profiles (in black) and the deep wells, superimposed. Featured geophysical domains (A, B and C). Shaded Image: Slope $=45^{\circ}$, declination $=80^{\circ} \mathrm{Az}$. EML - electromagnetic lineament (EML1: dashed white line, EML2: solid white line).

The second tectonic event, still not well understood, generated in the Oligocene-Miocene distension joints at lower depths, approximately along the N-S direction, related to lineaments EML1 and LL3 (Fig. 4C).

\section{Ground Electromagnetometry}

The three regional electromagnetic profiles of the study area presented high apparent conductivity values, even above $50 \mathrm{mS} / \mathrm{m}$ in the DV-10 dipole mode (coaxial with 10-m spacing between coils). However, the inductive magnetic field may be relatively little penetrative for this hardware configuration. Hence, penetrative anomalies are observed best in DV-20 and DV-40 dipole modes (coaxial with a spacing of 20 and $40 \mathrm{~m}$ between coils, respectively).

In Profile EM-01, the reading stations where relatively anomalous apparent conductivity values occur in both DV-20 and DV-40 dipole modes are approximately: 960-1000, 1240, 1680-1720, 2040-2080, 2560 and 2640-2680 m. For DV-20, apparent conductivity values are higher than $10 \mathrm{mS} / \mathrm{m}$, reaching $40 \mathrm{mS} / \mathrm{m}$ at stations 2560 and 2640-2680 m, while for DV-40 the minimum conductivity value is $10 \mathrm{mS} / \mathrm{m}$, in the stations with readings considered anomalous, with a maximum value of approxi- 


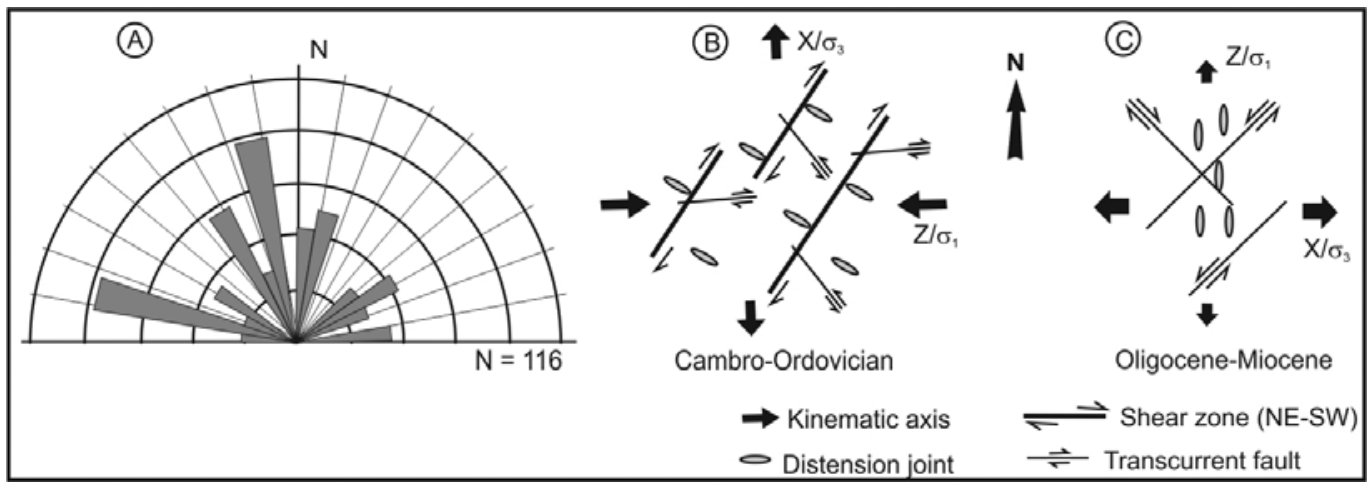

Figure $4-A$ ) Rosette diagram representative of fractures measured in the field, showing two main trends: NNW and WNW. B) and C) Kinematics of the major deformation events and brittle structures for Borborema Province, in Cambro-Ordovician (B) and Oligocene-Miocene (C) (modified from Jardim de Sá et al., 2008).

mately $30 \mathrm{mS} / \mathrm{m}$ at the $2560 \mathrm{~m}$ station (Fig. 5A). Reading stations 360, 1400, 2320, 2560 and 2680 m coincide with the conductive lineaments as featured in the aero-electromagnetic map (Fig. 3). However, there is anomalous correlation between airborne and ground geophysical data only at the last two reading stations.

Along the EM-02 profile (Fig. 5B) there are five reading stations with relatively anomalous apparent conductivity values for the two dipole modes (DV-20 and DV-40), as follows: 40, 360, 1120, 2400 and $2960 \mathrm{~m}$. The values range from 15 to $45 \mathrm{mS} / \mathrm{m}$ for DV-20 and from 15 to $50 \mathrm{mS} / \mathrm{m}$ for DV-40 dipole mode. Regarding the aero-electromagnetic map (Fig. 3), reading stations 40, 880, 1720 and $2960 \mathrm{~m}$ coincide with approximately NorthSouth conductive lineaments (EML1); however, there is correspondence between airborne and ground conductive anomalies only in the first and last reading station of this profile.

In EM-03 electromagnetic profile, the background of the measured apparent conductivity values is slightly less than $10 \mathrm{mS} / \mathrm{m}$ (Fig. 5C). Relatively anomalous data was obtained for both DV20 and DV-40, in reading stations 200, 1280, 1400-1520, 17601800, 1920-1960 and 3280-3320 m, whose values range from approximately 10 to $30 \mathrm{mS} / \mathrm{m}$ for DV-20 and approximately 10 to $20 \mathrm{mS} / \mathrm{m}$ for DV-40. Of the mapped anomalies, those occurring at stations 200, 1400, 1920 and $3280 \mathrm{~m}$ are correlated to conductive lineaments (EML1) of the aero-electromagnetic map (Fig. 3).

\section{LOCAL STRUCTURAL-HYDROGEOLOGICAL MODEL}

From the integration of all data discussed in this study, a local structural-hydrogeological model is proposed to guide hydrogeological prospecting work in similar crystalline terrains. In this model the brittle discontinuities along the NNW-SSE/NNE-SSW direction (approximately N-S) are little penetrative and more frequent. They are mainly responsible for the water recharge of the more penetrative and less frequent WNW-ESE geological struc- tures in the survey area, which are, therefore, more productive in terms of groundwater resources (Fig. 6, Table 1). This model is mainly based on the following observations and evidence:

- The mapping of the WNW-ESE magnetic lineaments by airborne magnetometry indicates the existence of penetrative geological structures in this direction, confirmed by satellite imaging and structural geology data obtained in the field;

- NNW-SSE/NNE-SSW lineaments (approximately N-S) were identified only in aero-electromagnetic data and not in the airborne magnetic data, which corroborates the fact that these geological structures are less penetrative than the WNW-ESE geological structures;

- Deep wells with $6-\mathrm{m}^{3} / \mathrm{h}$ outflow located in the central area of the Juá district are associated with a brittle WNW-ESE discontinuity. WNW-ESE geological discontinuities were mapped by airborne magnetic and electromagnetic methods (ML3 and EML2, respectively), as well as observed in satellite images (LL2) and rock outcrops;

- The water entries into the deep wells located on the basis of approximate N-S structures do not exceed 20 meters depth (SIAGAS/CPRM database), indicating that the geological structures oriented in this direction are relatively little penetrative. Approximately $78 \%$ of these wells exhibit outflow rate lower than $1 \mathrm{~m}^{3} / \mathrm{h}$;

- The brittle structural framework model of Borborema Province proposed by Jardim de Sá et al. (2008), according to which, brittle geological structures perpendicular to shear zones NESW are older and penetrative, while brittle N-S structures are newer and shallower. The northern portion of the Borborema Province presents important NE-SW shear zones. 


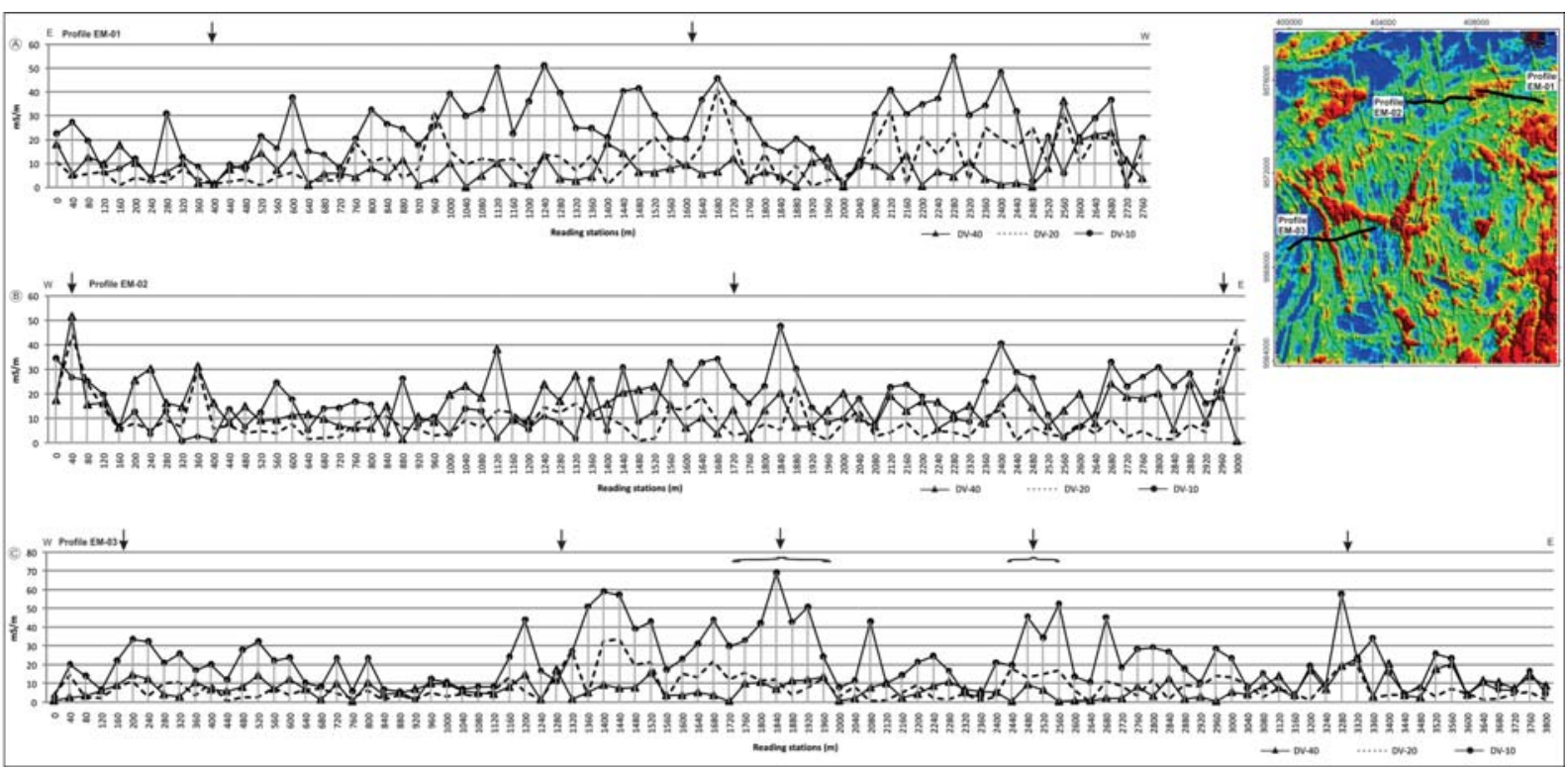

Figure 5 - Regional terrestrial electromagnetic profiles: EM_01, EM_02 and EM_03. Black arrows indicate points corresponding to the conductive lineaments in the aero-electromagnetic image. Aero-electromagnetic map with the location of terrestrial electromagnetic profiles.

Table 1 - Lineament characterization considering orientation, origin, geological structure, geological event responsible for its genesis and its hydrogeological potential.

\begin{tabular}{|c|c|c|c|c|c|c|}
\hline \multirow{2}{*}{ Orientation } & \multicolumn{3}{|c|}{ Lineament type } & \multirow{2}{*}{ Related structure type } & \multirow{2}{*}{$\begin{array}{c}\text { Geological event } \\
\text { (Arthaud, 2007; } \\
\text { Jardim de Sá et al., 2008) }\end{array}$} & \multirow{2}{*}{$\begin{array}{l}\text { Hydrogeological } \\
\text { potential }\end{array}$} \\
\hline & Magnetic & Eletromagnetic & LandSat & & & \\
\hline $\begin{array}{l}\text { N-S (inflection } \\
\text { to NE-SW) }\end{array}$ & ML1 & & LL1 & $\begin{array}{c}\text { Tectonometamorphic foliation/ } \\
\text { Geological contact }\end{array}$ & $\begin{array}{l}\text { Brasiliano Orogen } \\
\text { (Compression) }\end{array}$ & Null \\
\hline ENE-WSW & ML2 & & & Shear zone & $\begin{array}{c}\text { Brasiliano Orogen } \\
\text { (Shear) }\end{array}$ & Null \\
\hline WNW-ESE & ML3 & EML2 & LL2 & Frature/Fault & $\begin{array}{l}\text { Exhumation after } \\
\text { Brasiliano Orogen }\end{array}$ & $\begin{array}{l}\text { Medium } \\
\text { to high }\end{array}$ \\
\hline $\begin{array}{l}\text { NNW-SSE/ } \\
\text { NNE-SSW }\end{array}$ & & EML1 & LL3 & Frature/Fault & $\begin{array}{l}\text { Thermal Dome in the } \\
\text { Oligocene-Miocene? }\end{array}$ & $\begin{array}{l}\text { Low } \\
\text { to medium }\end{array}$ \\
\hline
\end{tabular}

\section{CONCLUSIONS}

Integrated analysis of airborne geophysical data, information from Landsat satellite images and structural geology data from the field determined the presence of four lineaments groups corresponding to different geological structures. The N-S turning to NE-SW and the ENE-WSW lineaments correspond to tectonic metamorphic foliations, lithological boundaries and shear zones that originated in a compressional tectonic event during the Brasiliano orogeny and are of no importance for groundwater resources exploration.

The two other groups of lineaments, WNW-ESE and NNWSSE/NNE-SSW trending, correspond to brittle discontinuities that originated in extensional tectonic events. The first, probably related to Brasiliano Post-Orogenic exhumation, corresponds to more penetrative and with better underground hydrogeological potential geological structures. The second group, probably related to thermal doming in the Oligocene-Miocene, represents little penetrative and more frequent geological structures, with lower hydrogeological potential than the WNW-ESE structures (Table 1).

The proposed structural-hydrogeological model does not rule out the potential of the NNW-SSE/NNE-SSW structures for underground water storage, especially since they may correspond to important recharge areas. It merely suggests that the WNWESE geological discontinuities are more likely to form important fissure aquifers, also considering that the most productive wells of the area are associated with one of these discontinuities near the Juá district, in the central area. 


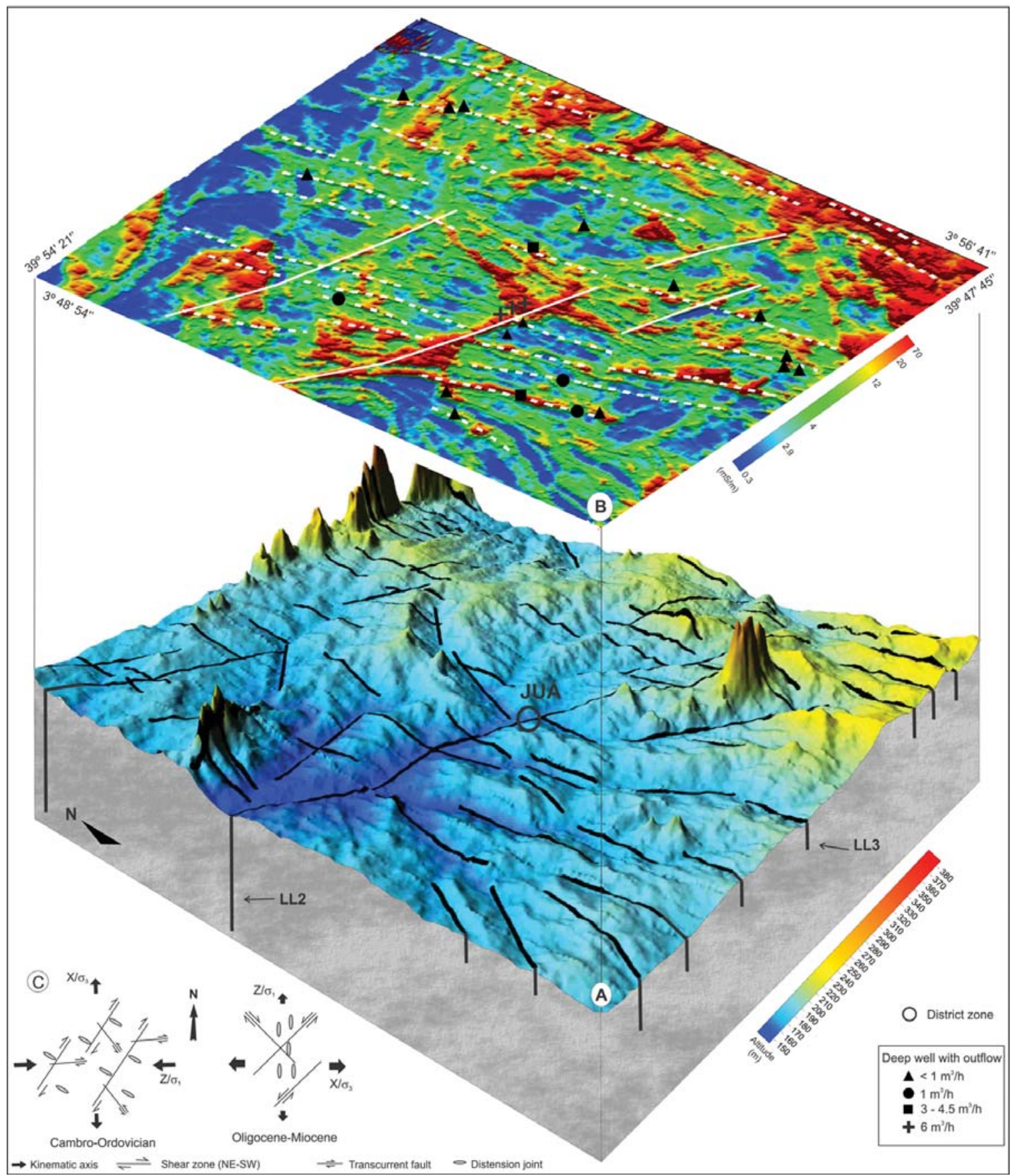

Figure 6 - Block diagram representing the proposed structural-hydrogeological model comprising: (A) Digital elevation model with superimposed Landsat lineaments LL2 (WNW-ESE) and LL3 (approximately N-S), (B) Aero-electromagnetic image with interpreted anomalous conductive lineaments with the deep wells superimposed and (C) kinematic models of the major deformation events and brittle structures for Borborema Province, in Cambro-Ordovician and Oligocene-Miocene.

The correlation of conductive anomalies highlighted in the ground electromagnetic profiles, with the structural data and the anomalous aero-electromagnetic lineaments, N-S trending, indicates the existence and position of geological discontinuities that could be associated to groundwater flow and storage, or at least refill conduits of major fissure aquifers. Therefore, they are considered promising prospective targets. However, detailed electrical and electromagnetic ground geophysical surveys associated 
with a structural analysis of the area, for better characterization of geological discontinuities of interest, are recommended.

\section{ACKNOWLEDGMENTS}

Thanks are due to Serviço Geológico do Brasil - CPRM, for providing the airborne geophysical data; Fundação Cearense de Apoio ao Desenvolvimento Científico e Tecnológico - FUNCAP, for financial support through Master's scholarship according to procedure 367/04; Laboratório de Geofísica de Prospecção e Sensoriamento Remoto - LGPSR da Universidade Federal do Ceará UFC, for providing the ground geophysical equipment and infrastructure needed for carrying out this research, and the reviewers of this paper for their suggestions.

\section{REFERENCES}

ALMEIDA FFM, HASUI Y, BRITO NEVES BB \& FUCK RA. 1981. Brazilian structural provinces: an introduction. Earth Sciences Reviews, 17: 1-29.

ARTHAUD MH. 2007. Evolução neoproterozóica do Grupo Ceará (Domínio Ceará Central, NE Brasil): da sedimentação à colisão continental brasiliana. Doctorade Thesis on Geosciences - Instituto de Geociências, Universidade de Brasilia, Brasília. 170 pp.

BRITO NEVES BB, CAMPOS NETO MC \& FUCK RA. 1999. From Rodinia to Western Gondwana: An approach to the Brasiliano-Pan African Cycle and Orogenic Collage. Episodes, Journal of International Geoscience, 22: $155-166$.

CASTRO NA. 2004. Evolução geológica proterozoica da região entre Madalena e Taperuaba, domínio tectônico Ceará central (Província Borborema). Doctorade Thesis. Universidade de São Paulo. 221 pp.

CAVALCANTE JC, VASCONCELOS AM, GOMES IP \& MEDEIROS MF. 2003. Atlas digital de geologia e recursos minerais do Ceará. Fortaleza: CPRM - Serviço Geológico do Brasil, CD-ROM. Escala 1:500.000.

CORIOLANO ACF. 2002. Reavaliação de critérios estruturais na hidrogeologia de terrenos cristalinos, com ênfase na neotectônica e sensoriamento remoto. Doctorade Thesis. Programa de Pós-Graduação em Geodinâmica e Geofísica. Universidade Federal do Rio Grande do Norte (UFRN). 197 pp.

DELGADO IM, SOUZA JD, SILVA LC, SILVEIRA FILHO NC, SANTOS RA, PEDREIRA AJ, GUIMARÃES JT, ANGELIM LAA, VASCONCELOS AM, GOMES IP, LACERDA FILHO JV, VALENTE CR, PERROTTA MM \& HEINECK CA. 2003. Geotectônica do Escudo atlântico. In: BIZZI LA, SCHOBBENHAUSC, VIDOTTI RM, GONÇALVES JH. Geologia, tectônica e recursos minerais do Brasil: texto, mapas e SIG. Brasília: CPRM Serviço Geológico do Brasil, 227-334.

FEITOSA EC, OLIVEIRA RG \& DEMETRIO JGA. 2008. Métodos geofísicos. In: FEITOSA FAC, MANOEL FILHO J, FEITOSA EC, DEMETRIO
JGA. 2008. Hidrogeologia: conceitos e aplicações. 3 ed. Rio de Janeiro: CPRM, LABHID., 209-254.

FETTER AH. 1999. U/Pb and Sm/Nd geochronological contraints on the crustal framework and geologic history of Ceará state, NW Borborema province, NE Brazil: implications for the Assembly of Gondwana. Doctorade Thesis on Geology - Department of Geology, University of Kansas, Kansas. $164 p$.

FETTER AH, SANTOS TJS, VAN SCMUS WR, HACKSPACHER PC, BRITO NEVES BB, ARTHAUD MH, NOGUEIRA NETO JA \& WERNICK E. 2003. Evidence for neoproterozoic continental arc magmatism in the Santa Quitéria batholith of Ceará state, NW Borborema Province, NE Brazil: Implications for the Assembly of West Gondwana. Gondwana Research, 6(2): 265-273.

JARDIM DE SÁ EF, SILVA CCN, CORIOLANO ACF \& MEDEIROS WE. 2008. Conceitos de análise estrutural aplicados à hidrogeologia de terrenos cristalinos. In: FEITOSA FAC, MANOEL FILHO J, FEITOSA EC, DEMETRIO JGA. 2008. Hidrogeologia: conceitos e aplicações. 3 ed. Rio de Janeiro: CPRM, LABHID, 97-120.

LASA (ENGENHARIA E PROSPECÇ̃̃O S.A.). 2001. Relatório Final do Levantamento e Processamento dos Dados Magnetométricos e Eletromagnetométricos e Seleção das Anomalias Eletromagnéticas. Projeto Aerogeofísico Água Subterrânea do Nordeste do Brasil. Texto Técnico, V. 1, 82 p. <http://proasne.net>.

LEITE CES. 2008. Sensoriamento Remoto. In: FEITOSA FAC, MANOEL FILHO J, FEITOSA EC, DEMETRIO JGA. 2008. Hidrogeologia: conceitos e aplicações. 3 ed. Rio de Janeiro: CPRM, LABHID, 273-292.

MCNEILL JD. 1980. Electromagnetic Terrain Conductivity Measurement at Low Induction Numbers. TN-6, Geonics Inc., Mississauga, Ontario. $15 \mathrm{pp}$.

OLIVEIRA RG, GALVÃO MJTG \& AMARAL CA. 2003. Aplicação de métodos eletromagnetométrico e magnetométrico levantados por helicóptero para a pesquisa de água subterrânea em rochas cristalinas fraturadas na área-piloto Samanbaia, vale do rio Moxotó-PE, Brasil. In: $8^{\text {th }}$ International Congress of the Brazilian Geophysical Society. 16. CD-ROM.

PATERSON NR \& BOSSCHART RA. 1987. Airborne geophysical exploration for ground water. Ground Water, 25(1): 41-50.

PORSANI JL, ELIS VR \& HIODO FY. 2005. Geophysical investigations for the characterization of fratured rock aquifers in Itu, SE Brazil. J. Appl. Geophysics, 57: 119-128.

RANGANAI RT \& EBINGER CJ. 2008. Aeromagnetic and landsat TM structural interpretation for identifying regional groundwater exploration targets, south-central Zimbabwe Craton. J. Appl. Geophysics, 65: 7383. 
REEVES CC \& ZEIL PW. 1990. Airborne geophysics and remote sensing: some commom ground in presentation techniques and interpretation. IMM Remote sensing volume, 75-88.

SANDER P. 2007. Lineaments in groundwater exploration: a review of applications and limitations. Hydrogeology Journal, 15: 71-74.

SIEMON B, CHRISTIANSEN AV \& AUKEN E. 2009. A review of helicopter-borne electromagnetic methods for groundwater exploration. Near Surface Geophysics, 629-646.

SIEMON B, STEUER A, ULLMANN A, VASTERLING A \& VOB W. 2011. Application of frequency-domain helicopter-borne electromagnetic for groundwater exploration in urban areas. Physics and Chemistry of the Earth, 36(16): 1373-1385.

SOUZA FILHO OA. 1998. Geologia e Mapa de Previsão de Ocorrência de Água Subterrânea Folha SA. 24-Y-D-V - Irauçuba, Ceará. Master Dis- sertation. Universidade Federal de Ouro Preto-MG. 99 pp.

SOUZA FILHO A0. 1999. Programa levantamentos geológicos básicos do Brasil. Irauçuba, folha SA.24-Y-D-V. CPRM, Brasília, 1:100.000.

SOUZA FILHO OA, SILVA AM, REMACRE AZ, SANCEVERO SS, McCAFFERTY AE \& PERROTTA MM. 2010. Using helicopter electromagnetic data to predict groundwater quality in fractured crystalline bedrock in a semi-arid region, Northeast, Brazil. Hydrogeology Journal, 18: 905-916.

TORRES PFM, CAVALCANTE JC, SMITH EP, VASCONCELOS AM \& OLIVEIRA FV. 2007. Mapa geológico da folha Quixadá (SB-24-V-CVI). Programa Levantamentos Geológicos Básicos. CPRM - Serviço Geológico do Brasil, Fortaleza-CE, 1:250.000.

YADAV GS \& SINGH SH. 2007. Integrated resistivity surveys for delineation of fractures for ground water exploration in hard rock areas. J. Appl. Geophysics, 62: 301-312.

Recebido em 11 outubro, 2012 / Aceito em 28 junho, 2013

Received on October 11, 2012 / Accepted on June 28, 2013

\section{NOTES ABOUT THE AUTHORS}

Tercyo Rinaldo Gonçalves Pinéo. Geologist (UFC-2003), M.Sc. in Hydrogeology (UFC-2005). Participated in research projects with focus on remote sensing and electrical and electromagnetic geophysical methods applied to hydrogeology and the environment, while a member of the Laboratório de Geofísica de Prospecção e Sensoriamento Remoto da Universidade Federal do Ceará. Currently working as a Geologist/Researcher in Geosciences at CPRM (Serviço Geológico do Brasil) engaging in geological mapping activities and handling of airborne geophysical data (magnetic and radiometric) applied to geological mapping and mineral exploration, since 2007.

Raimundo Mariano Gomes Castelo Branco. Geologist (UFC), M.Sc. in Geochemistry and Geotectonics (USP) and PhD in Geophysics and Remote Sensing at the University of Nantes in France. Associate Professor, Department of Geology at UFC and Graduate Program in Geology from the UFC and LABOMAR, and connected to the University of Cagliari in Italy. Works in geophysics applied to aquifer systems, modeling and the environment, as well as in non-seismic methods applied to oil and gas. Geophysical investigations involve electric and electromagnetic methods (MT, CSAMT, TDEM, EM, GPR), potential fields (GRAV, MAG) and logging. Coordinates projects with the main research funding agencies, CENPES/PETROBRAS and CPRM.

Luciano Soares da Cunha. Bachelor's Degree in Geology from the Universidade de Brasilia - UNB, M.Sc. in Hydrogeology from the Universidade Federal do Ceará, PhD from UNB and currently Associate Professor at Instituto de Geociências da Universidade de Brasília. Researching the interface between hydrogeology and shallow geophysics applied to the environment. This research is structured in the acquisition, processing and data integration in GIS and 3D modeling. Research in hydrogeology includes hydrochemical studies of contamination and pollution of aquifers, groundwater flow modeling, vulnerability and risk, forecasting models. The geophysical investigations involve electrical and electromagnetic methods in the time and frequency domain.

Mauro Lisboa Souza. Bachelor's Degree in Geology from Universidade Federal do Ceará - UFC, M.Sc. in Hydrogeology from the Universidade Federal do Ceará - UFC and currently a Researcher in Geosciences at CPRM - Serviço Geológico do Brasil. Working in the marine geophysical and geological research, in projects related to cobalt crust and hydrothermal sulfides, in international oceanic area projects, and also in research on marine mineral resources of the Brazilian continental shelf. Analyzes multibeam bathymetry, sub-bottom acoustic profiles, magnetic and gravity data, correlating their features with rocks and sediments samples collected punctually, by dredging or coring. 